\title{
Responses of Rice Mini-Core Collection Accessions to Damage by Diatraea saccharalis (Fabricius) Stem Borer
}

\author{
Jacqueline Barbosa Nascimento ${ }^{1}$, José Alexandre de Freitas Barrigossi² \\ ${ }^{1}$ Department of Entomology, Faculty of Agronomy, Federal University of Goiás, Goiânia, Brazil \\ ${ }^{2}$ Embrapa Rice and Beans, Santo Antônio de Goiás, Brazil \\ Email: josé.barrigossi@embrapa.br
}

Received 15 May 2014; revised 26 June 2014; accepted 15 July 2014

Copyright (C) 2014 by authors and Scientific Research Publishing Inc.

This work is licensed under the Creative Commons Attribution International License (CC BY). http://creativecommons.org/licenses/by/4.0/

(c) (i) Open Access

\section{Abstract}

This study aimed to observe the response of 32 rice accessions to attack of sugarcane borer (Diatraea saccharalis Fabr., 1794). Twenty larvae were placed on the leaf sheaths of rice plants. At 30 days after infestation, the rice plants were cut at ground level and taken to the laboratory to analyse the signs of borer attack, external and internal diameter of the stem and weight of surviving larvae. The results of the morphological traits of the rice plant, response of the plant to insect attack and development of the sugarcane borer larvae indicated a genotypic variation. The accessions that most favored larval survivals were IRAT 124 and MEARIN. Larvae with highest weight $(0.0643 \mathrm{~g})$ were found in IAPAR L 99-98 and the largest internal diameters of the rice stem $(5.65 \mathrm{~mm})$ were found in LAC 12. These accessions (IRAT 124, MEARIN, IAPAR L 99-98 and LAC 12) remained morphologically grouped with IAC 47, cultivar susceptible to sugarcane borer. The most tolerant materials based on the ability to produce new tillers after larval infestation were BR IRGA 417 and MTU 15. The results of this study indicate that all the morphological traits were able to separate the accessions of rice into different groups in relation to resistance to the sugarcane borer D. saccharalis. These materials can be used as donor sources in pre-breeding for genetic resistance to sugarcane borers.

\section{Keywords}

Rice, Sugarcane Borer, Morphological Traits, Resistance

\section{Introduction}

Rice is one of the most important cereals in the world, which is responsible in developing countries for $95.2 \%$ of

How to cite this paper: Nascimento, J.B. and de Freitas Barrigossi, J.A. (2014) Responses of Rice Mini-Core Collection Accessions to Damage by Diatraea saccharalis (Fabricius) Stem Borer. Agricultural Sciences, 5, 776-784. 
global consumption and $95.9 \%$ of production. Brazil ranks ninth in the world production and first outside the Asian continent [1]. Yield can be affected by several abiotic and biotic factors [2]. In regards to the biotic factors, insects are the pests that cause the most damage to this crop; and among these insects, the sugarcane borer Diatraea saccharalis Fabricius (Lepidoptera: Crambidae) is found all over the Brazil infesting various grasses and causing economic losses in crops of upland and irrigated rice. This insect is of major importance for rice in the North and Midwest regions of Brazil [3].

The increased level of sugarcane borer damage to upland rice in recent years has been primarily observed in the state of Mato Grosso, Brazil. The increased damage in Mato Grosso is attributed to the expansion of corn (Zea mays) and sugarcane (Saccharum officinarum), which are primary hosts of the sugarcane borer [4]. The largest problem in the effective management of this pest is the difficulty in monitoring in order to detect the pest before damage occurs. It is most easily detected only after penetration of the stem and the production of whiteheads or dead panicles [5]-[9]. It is also difficult to control with pesticides, as proper timing of application is difficult. Moreover, no pesticides are registered for control of the sugarcane borer in Brazilian rice [4].

Host plant resistance (HPR) is a practical way to overcome the stem borer constraint in rice production, and may be a particularly appropriate and important tactic against these insects [10]. Morphological traits are an important factor in conferring HPR, and are responsible for the suitability of a cultivar for feeding by the insects as well as oviposition and development. In many crop species, the degree of a genotype's resistance to insect pests is associated with the plant's morphological characteristics. Borer damage has been reported to affect plant growth and specifically ear development, which negatively impacts grain yield. The number of exit holes is an indication of the number of borers that have successfully completed their life cycle within a stem, while the stem tunnels indicate the extent of plant damage [11] [12].

Host plant resistance has been a major focus of stem borer management studies in both Asia and the United States [13]-[15]. However, limited studies have been conducted to identify sugarcane borer resistant cultivars in Brazil, and there are no identified donor cultivars in the Brazilian genotypes with adequate resistance to the borers for use in the breeding program. Thus, there is a need to enhance the levels of genetic resistance of adapted Brazilian cultivars for use as a component in the integrated management of the sugarcane borer in upland rice.

The objective of this study was to evaluate the response of 32 accessions of the rice mini-core collection of the genebank of the Brazilian Agricultural Research Corporation (Embrapa) Rice and Beans to infestations of the sugarcane borer $D$. saccharalis, identifying sources of resistance to this borer, and to correlate insect resistance with morphological characteristics of the plants.

\section{Materials \& Methods}

\subsection{Plant Material}

A total of 32 accessions of Oryza sativa were included in this study (Table 1). These accessions have been maintained at EMBRAPA Rice and Beans Center, located in Santo Antônio de Goiás, Goiás (GO), Brazil (altitude $749 \mathrm{~m} ; 16^{\circ} 40^{\prime} 43^{\prime \prime} \mathrm{S} ; 4^{\circ} 15^{\prime} 14^{\prime \prime} \mathrm{W}$ ). The rice accessions selected for this study are genotypes of the subspecies indica and japonica with a wide genetic divergence between them, constituents of the rice mini-core collection [16]. The accessions have potential to be good donors in the pre-breeding program as based in the adaptation to the upland rice production in areas where conditions of stem borers is becoming of increasing importance in Brazil.

\subsection{Evaluation of the Resistance Trait of Rice Accessions}

The response of rice due to sugarcane borer attack was determined in greenhouse under natural conditions (temperature and relative humidity were recorded by a datalogger model AZ 8829). The water irrigation was performed once a day, and a weeding was used only as weed control. The fertilizer recommended was followed by Sousa and Lobato [17]. The experimental design was a randomized block with ten replications. A replication consisted of ten plants, each of which was infested with two neonate larvae of $D$. saccharalis per plant.

The neonate $D$. saccharalis larvae used to infest the rice plants were obtained from eggs provided by the company Biocontrol ${ }^{\circledR}$, Sertãozinho, SP, Brazil where the borer was reared on an artificial diet [21]. The cards with the eggs of the sugarcane borer were treated with copper sulfate in the laboratory of Biocontrol ${ }^{\circledR}$ and shipped to Goiás. There they were maintained until larval emergence in the EMBRAPA Rice and Beans Entomology laboratory in acrylic type $350 \mathrm{ml}$ germination boxes (Gerbox) [22] also containing moistened cotton. 
Table 1. Identification number, crop system, origin, common name and level of resistance to rice stem borers of selected rice accessions in the mini-core collection of the Embrapa Rice and Beans genebank.

\begin{tabular}{|c|c|c|c|c|c|c|}
\hline $\begin{array}{l}\text { Identification } \\
\text { number }^{1}\end{array}$ & $\begin{array}{l}\text { Crop } \\
\text { system }\end{array}$ & $\begin{array}{c}\text { Country of } \\
\text { origin }\end{array}$ & $\begin{array}{l}\text { Common } \\
\text { name }\end{array}$ & $\begin{array}{l}\text { Levels of } \\
\text { resistance }\end{array}$ & $\begin{array}{l}\text { Stem borer } \\
\text { species }\end{array}$ & Reference \\
\hline CNA0002293 & Irrigated & Thailand & KU 94-2 & - & - & - \\
\hline CNA0002416 & Irrigated & Liberia & LAC 12 & - & - & - \\
\hline CNA0002258 & Irrigated & Thailand & KU 56-3 & - & - & - \\
\hline CNA0008229 & Irrigated & India & BASMATI 370 & - & - & - \\
\hline CNA0002672 & Irrigated & Thailand & NAHNG PAYA 132 & - & - & - \\
\hline CNA0010675 & Irrigated & Brasil & BR IRGA 417 & - & - & - \\
\hline CNA0007553 & Irrigated & Brasil & BRS FORMOSO & - & - & - \\
\hline CNA0005014 & Irrigated & China & WU $10 \mathrm{~B}$ & - & - & - \\
\hline CNA0002480 & Irrigated & Cameroon & M 40 & - & - & - \\
\hline CNA0002442 & Irrigated & USA & LEBONNET & - & - & - \\
\hline CNA0003195 & Irrigated & Egypt & GZ 944-5-2-2 & - & - & - \\
\hline CNA0010433 & Irrigated & Japan & MOGAMI CHIKANARI & - & - & - \\
\hline CNA0006961 & Irrigated & Italy & VITRO & - & - & - \\
\hline CNA0005853 & Irrigated & Russia & WIR 5621 & - & - & - \\
\hline CNA0010438 & Irrigated & Japan & TOMOE MOCHI & - & - & - \\
\hline CNA0002881 & Irrigated & Portugal & RIZZOTO 159 & - & - & - \\
\hline CNA0003005 & Upland & India & SONA & - & - & - \\
\hline CNA0005461 & Upland & India & CO 18 & Resistent & $\begin{array}{l}\text { Scirpophaga } \\
\text { incertulas }\end{array}$ & [18] \\
\hline CNA0005462 & Upland & India & MTU 15 & Resistent & $\begin{array}{c}\text { Chilo suppressalis } \\
\text { Scirpophaga } \\
\text { incertulas }\end{array}$ & [18] \\
\hline CNA0003490 & Upland & France & MEARIN & - & - & - \\
\hline CNA0005465 & Upland & India & W 1253 & - & - & - \\
\hline CNA0010503 & Upland & Philippines & YN1905-UUL-62 & - & - & - \\
\hline CNA0006422 & Upland & Brazil & IAPAR L 99-98 & - & - & - \\
\hline CNA0004480 & Upland & France & IRAT 124 & - & - & - \\
\hline \multirow[t]{2}{*}{ CNA0004759 } & Upland & Nigeria & TOX514-16-101-1 & - & - & - \\
\hline & Upland & Brazil & CURINGA & - & - & - \\
\hline CNA0005287 & Upland & France & IRAT 162 & - & - & - \\
\hline CNA0010476 & Upland & Philippines & B8503-ТВ-19-B-3 & - & - & - \\
\hline CNA0008070 & Upland & Brazil & BRS PRIMAVERA & $\begin{array}{l}\text { Moderately } \\
\text { resistant }\end{array}$ & Diatraea saccharalis & [19] [20] \\
\hline CNA0004243 & Upland & India & OR 63-252 & - & - & - \\
\hline CNA 0002023 & Upland & Brazil & IAC 47 & Susceptible & $\begin{array}{c}\text { Elasmopalpus } \\
\text { lignosellus } \\
\text { Diatraea saccharalis }\end{array}$ & [5] [20] \\
\hline CA 220268 & Upland & Brazil & CANELA DE FERRO & & & - \\
\hline
\end{tabular}

${ }^{1}$ The identification number used in the Embrapa Rice and Beans genebank.

The neonate larvae were placed on the leaf sheaths of rice plants with a fine camel's hair brush. Thirty days after infestation, the rice plants were cut close to the ground and taken to the laboratory where the stems were examined. The following phenotypic data of the accessions were recorded: NLL-number of live larvae/stem; IM-individual mass in grams of surviving worms; ED-external diameter of the stem; ID-internal diameter of the stem; NTT-number of total tillers by 30 days after larval infestation (period corresponding to the last 
larval instar); NSA—number of stems attacked after larval infestation and NLD—number of stems with no larval damage after larval infestation. The diameters of the stem were measured with a caliper model DIGIMESS in the middle part of the plants.

\subsection{Statistical Analyses}

The data collected in this study were not normally distributed. Thus, we opted for the non-parametric analysis. The Kruskal-Wallis test was performed to evaluate differences among the rice accessions. [23], while multivariate statistics were performed to verify the separation of groups in the population for resistance to $D$. saccharalis. A CVA (Canonical Variable Analysis), the matrix of Mahalanobis distance $\left(\mathrm{D}^{2}\right)$ and Tocher's grouping method [24] was calculated using GENES software [25].

\section{Results and Discussion}

\subsection{Evaluation of the Resistance Trait of Rice Accessions}

\subsubsection{Univariate Analysis}

The phenotypic response of rice accessions to the borer, $D$. saccharalis, was significant $(\mathrm{P}<0.05)$ by KruskalWallis test at $5 \%$ significance level, for the traits evaluated which indicated of the occurrence a genetic variation (Table 2). The accesses that were more favorable to the survival of stem borers were IRAT 124 and MEARIN. Among the accessions with the lowest number of live larvae were KU 94-2 and BRS PRIMAVERA which indicated that they were less favorable to the survival of the insect. This was probably due to the antibiotic effect of cultivars on insect biology (Table 2).

With the total number of stems after infestation (NTT) and normal stem (NLD), it was observed that BASMATI 370, BR IRGA 417, BRS FORMOSO, SONA, MTU15, MEARIN and W1253 were more tillers after infestation and a higher number of normal stem at the end of the experiment, which was indicative of favorable characteristics of the presence of resistance of the type tolerance by the sugarcane, respectively (Table 2).

There is also a relationship between survival (NLL) and individual mass (IM) of surviving larvae with the external diameter (ED) and internal diameter (ID) of the stem. This indicates that the larvae were heavier and had greater survival chances when feeding on plants with larger stem diameters. The morphological characteristics (large external diameter of the stem and an internal diameter of the stem greater than $2.5 \mathrm{~mm}$ ) which favored the growth and development of the sugarcane borer are common in susceptible accessions.

\subsubsection{Multivariate Analysis}

The genetic dissimilarity estimated by the Mahalanobis distance $\left(\mathrm{D}_{2}\right)($ Table 3$)$ indicated that the accessions that were most divergent (dissimilar) ( $\mathrm{D}^{2}$ max: 21.99) were accession WU 10B (accession ID 8) and IAPAR L 99-98 (23), while MOGAMI-CHIKANARI (ID 12) and CO18 (ID 18) were the most similar ( $\mathrm{D}^{2}$ min: 0.35 ). With the cluster analysis by Tocher's grouping method, it was possible to observe four groups (Table 4), with the largest number (21) of accessions in Group I. This group had important traits for susceptibility to the sugarcane borer while the third group (Table 4) consisted of accessions (8: WU 10 B; 10: LEBONNET, 11: GZ 944-5-2-2, 29: BRS PRIMAVERA) that were with traits for resistance indicated in Table 2.

By employment of the canonical variable analysis (CVA) clustering method, it was possible to observe the distribution of accessions in a two-dimensional graph (Figure 1). The positions of the accessions in the graph were apparently distributed into two groups, one large (Group I) and one medium (Group II) and one isolated accession (WIR 5621) as the most divergent. The first three canonical variables explained $87.52 \%$ of the total variability available (Figure 1) among the seven characters (Table 2) describing the 32 rice accessions.

The results of this analysis allow inferences about the response of the accession under study, which is useful information in determining the number of groups in the cluster analysis. The graphic dispersion of scores of the three canonical variables shows good agreement with the Tocher's grouping method, allowing the cultivars ID $14,8,10,11$ and 29 as the most divergent compared others. The use of multivariate analysis allows the identification of parents with genetic divergence and has been studied in breeding programs [26] [27]. Another important fact that should be considered in the choice of parents is whether they belong to different groups, in order to avoid crossing between parents belonging to the same group [25].

Various morphological traits of the rice plant were found to be associated with resistance to the stem borer. The resistance in rice to stem borer was low to moderate and appeared to be under polygenic control [28]. Many 
morphological, anatomical, physiological, and biochemical factors have been reported to be associated with resistance, each controlled by different sets of genes. Positive correlations were recorded between the number of bored stems and stem diameters, stem thickness, length and width of flag leaves and number of tillers per plant.

The rice accessions with higher tiller and thinner stem diameter such as BR IRGA 417, SONA and MTU 15 were tolerant to sugarcane borer, because thin stem diameter characteristics does not allow larvae to feed and develop inside the plant colm [29]. This meant that with increasing stem diameters, the number of larvae was increased. The data showed that accessions with higher tillering capability after infestation have a distinct capability to recover from the damage caused by the stem borer. The rice resistance to sugarcane borers is associated with tillering capacity of the plant after infestation, a characteristic of tolerant genotypes [7].

Table 2. Number of live larvae on the plant (NLL), individual mass (IM) in grams of surviving larvae, external diameter of stem (ED) and internal diameter of stem (ID) in mm, number of total tillers produced (NTT), number of stems attacked (NSA) and number of stems with no larval damage (NLD) after larval infestation on 32 rice accessions evaluated to detect resistance to Diatraea saccharalis.

\begin{tabular}{|c|c|c|c|c|c|c|c|}
\hline \multirow{2}{*}{ Accessions $^{\mathrm{a}}$} & \multicolumn{7}{|c|}{ Average } \\
\hline & NLL & IM & ED & ID & NTT & NLD & NSA \\
\hline 1-KU 94-2 & $2.4 \mathrm{~d}$ & 0.0321 abcde & 4.89 abcd & $2.66 \mathrm{abc}$ & $10.3 \mathrm{ab}$ & $7.0 \mathrm{a}$ & $3.3 \mathrm{ab}$ \\
\hline 2-LAC 12 & 7.5 abcd & 0.0274 bcde & $5.65 \mathrm{a}$ & $2.95 \mathrm{a}$ & $10.2 \mathrm{ab}$ & $6.6 \mathrm{ab}$ & $3.6 \mathrm{ab}$ \\
\hline 3-KU 56-3 & 3.5 abcd & 0.0385 abcde & $5.15 \mathrm{ab}$ & $2.80 \mathrm{ab}$ & $10.1 \mathrm{ab}$ & $7.3 \mathrm{a}$ & $2.8 \mathrm{ab}$ \\
\hline 4-BASMATI 370 & $7.5 \mathrm{abc}$ & $0.0527 \mathrm{ab}$ & 4.12 abcdefgh & 2.05 abcdefghi & $11.8 \mathrm{a}$ & $7.5 \mathrm{a}$ & $4.3 \mathrm{ab}$ \\
\hline 5-NAHNG PAYA 132 & 4.6 abcd & 0.0199 cde & 4.63 abcde & 2.54 abcdef & $9.8 \mathrm{ab}$ & $6.5 \mathrm{ab}$ & $3.3 \mathrm{ab}$ \\
\hline 6-BR IRGA 417 & $7.4 \mathrm{abcd}$ & $0.0553 a b$ & 3.85 abcdefgh & 1.97 bcdefghij & $12.8 \mathrm{a}$ & $7.4 \mathrm{a}$ & $5.4 \mathrm{a}$ \\
\hline 7-BRS FORMOSO & 5.7 abcd & 0.0395 abcde & 4.27 abcdefg & 2.09 abcdefgh & $11.2 \mathrm{a}$ & $7.0 \mathrm{a}$ & $4.2 \mathrm{ab}$ \\
\hline 8-WU 10 B & 3.9 abcd & 0.0137 de & $2.94 \mathrm{gh}$ & $1.27 \mathrm{j}$ & $8.9 \mathrm{ab}$ & $5.8 \mathrm{ab}$ & $3.1 \mathrm{ab}$ \\
\hline 9-M 40 & 7.6 abcd & 0.0337 abcde & 4.29 abcdef & 2.16 abcdefgh & $10.4 \mathrm{ab}$ & $5.6 \mathrm{ab}$ & $4.8 \mathrm{ab}$ \\
\hline 10-LEBONNET & 2.9 bcd & 0.0115 e & $3.44 \mathrm{fgh}$ & 1.67 hij & $10.4 \mathrm{ab}$ & $7.6 \mathrm{a}$ & $2.8 \mathrm{ab}$ \\
\hline 11-GZ 944-5-2-2 & $4.8 \mathrm{abcd}$ & 0.0209 cde & $3.07 \mathrm{~h}$ & $1.39 \mathrm{ij}$ & $11.3 \mathrm{a}$ & $6.9 \mathrm{ab}$ & $4.4 \mathrm{ab}$ \\
\hline $\begin{array}{l}\text { 12-MOGAMI } \\
\text { CHIKANARI }\end{array}$ & 4.7 abcd & 0.0360 abcde & $3.56 \mathrm{fgh}$ & 1.83 efghij & $10.2 \mathrm{ab}$ & $6.1 \mathrm{ab}$ & $4.1 \mathrm{ab}$ \\
\hline 13-VITRO & $6.3 \mathrm{abcd}$ & 0.0445 abcde & $4.93 \mathrm{abcd}$ & $2.63 \mathrm{abcd}$ & $9.9 \mathrm{ab}$ & $6.4 \mathrm{ab}$ & $3.5 \mathrm{ab}$ \\
\hline 14-WIR 5621 & 6.1 abcd & 0.0401 abcde & 3.24 fgh & 1.70 defghij & $4.6 \mathrm{~b}$ & $1.1 \mathrm{~b}$ & $3.5 \mathrm{ab}$ \\
\hline 15-TOMOE MOCHI & 3.4 abcd & 0.0263 bcde & 4.24 abcdefg & 2.16 abcdefgh & 10.9 a & $6.5 \mathrm{ab}$ & $4.4 \mathrm{ab}$ \\
\hline 16-RIZZOTO 159 & $7.7 \mathrm{ab}$ & 0.0452 abcd & 4.05 abcdefgh & 2.01 abcdefgh & $9.3 \mathrm{ab}$ & $5.1 \mathrm{ab}$ & $4.2 \mathrm{ab}$ \\
\hline 17-SONA & 5.7 abcd & $0.0552 \mathrm{abc}$ & 3.66 defgh & 1.80 efghij & $12.5 \mathrm{a}$ & $7.8 \mathrm{a}$ & $4.7 \mathrm{ab}$ \\
\hline 18-CO18 & $5.1 \mathrm{abcd}$ & 0.0380 abcde & 3.66 efgh & 1.91 defghij & $11.2 \mathrm{a}$ & $6.3 \mathrm{ab}$ & $4.9 \mathrm{ab}$ \\
\hline 19-MTU 15 & 4.6 abcd & 0.0451 abcd & 3.83 bcdefgh & $1.68 \mathrm{hij}$ & $12.4 \mathrm{a}$ & $8.3 \mathrm{a}$ & $4.1 \mathrm{ab}$ \\
\hline 20-MEARIN & $8.0 \mathrm{abc}$ & 0.0444 abcd & 3.87 bcdefgh & 1.98 bcdefghij & $12.3 \mathrm{a}$ & $7.5 \mathrm{a}$ & $4.8 \mathrm{ab}$ \\
\hline 21-W 1253 & $5.1 \mathrm{abcd}$ & 0.0452 abcd & 3.72 defgh & 1.76 ghij & $11.1 \mathrm{a}$ & $7.6 \mathrm{a}$ & $3.5 \mathrm{ab}$ \\
\hline 22-YN1905-UUL-62 & 4.5 abcd & 0.0479 abcd & 4.44 abcdef & 2.22 abcdefgh & $9.3 \mathrm{ab}$ & $5.9 \mathrm{ab}$ & $3.4 \mathrm{ab}$ \\
\hline 23-IAPAR L 99-98 & 6.6 abcd & $0.0643 \mathrm{a}$ & 4.29 abcdefg & 2.32 abcdefgh & $9.6 \mathrm{ab}$ & $4.9 \mathrm{ab}$ & $4.7 \mathrm{ab}$ \\
\hline 24-IRAT 124 & 8.6 a & $0.0553 a b$ & 3.79 bcdefgh & 1.86 defghij & $10.4 \mathrm{ab}$ & $5.6 \mathrm{ab}$ & $4.8 \mathrm{ab}$ \\
\hline 25-TOX 514-16-101-1 & 5.5 abcd & $0.0497 \mathrm{abc}$ & 3.82 bcdefgh & 1.94 defghij & $10.6 \mathrm{a}$ & 6.7 a & $3.9 \mathrm{ab}$ \\
\hline 26-BRS CURINGA & 3.3 abcd & 0.0318 abcde & 4.39 abcdef & 2.24 abcdefgh & $10.3 \mathrm{ab}$ & 6.9 a & $3.4 \mathrm{ab}$ \\
\hline 27-IRAT 162 & 3.4 abcd & 0.0458 abcde & $4.96 \mathrm{abc}$ & 2.40 abcdefg & $8.5 a b$ & $6.4 \mathrm{a}$ & $2.1 \mathrm{~b}$ \\
\hline 28-B8503-ТВ-19-B-3 & $6.4 \mathrm{abcd}$ & $0.0514 \mathrm{abc}$ & 4.10 abcdefgh & 1.95 cdefghij & $10.8 \mathrm{a}$ & $5.7 \mathrm{ab}$ & $5.1 \mathrm{ab}$ \\
\hline 29-BRS PRIMAVERA & $2.8 \mathrm{~cd}$ & 0.0247 bcde & 3.34 fgh & 1.77 fghij & $9.2 \mathrm{ab}$ & $6.0 \mathrm{ab}$ & $3.2 \mathrm{ab}$ \\
\hline 30-OR 63-252 & 4.5 abcd & 0.0325 abcde & 3.78 cdefgh & 1.77 ghij & $9.5 \mathrm{ab}$ & $6.4 \mathrm{ab}$ & $3.1 \mathrm{ab}$ \\
\hline 31-IAC 47 & 4.9 abcd & 0.0352 abcde & $5.00 \mathrm{ab}$ & 2.55 abcde & $10.0 \mathrm{ab}$ & $6.0 \mathrm{ab}$ & $4.0 \mathrm{ab}$ \\
\hline 32-CANELA DE FERRO & 4.9 abcd & 0.0285 bcde & $5.00 \mathrm{abc}$ & 2.51 abcdef & $8.6 \mathrm{ab}$ & $5.8 \mathrm{ab}$ & $2.8 \mathrm{ab}$ \\
\hline CV (\%) & 64.13 & 60.12 & 23.7 & 28.21 & 28.08 & 42.78 & 46.65 \\
\hline
\end{tabular}

${ }^{\mathrm{a}}$ Numbers 1 - 32 preceding the accession name refer to arbitrary numbers used to identify the accessions evaluated in this study. 
Table 3. Dissimilarity, based on the Mahalanobis distance $\left(\mathrm{D}^{2}\right)$, between pairs of accessions of rice for the seven characters measured: number of live larvae (NLL); individual mass of larvae in g (IM); external diameter of the stem (ED) and internal diameter of the stem in mm (ID); number of tillers produced after infestation (NTP); number of stems attacked (NSA); number of stems with no larval damage (NLD).

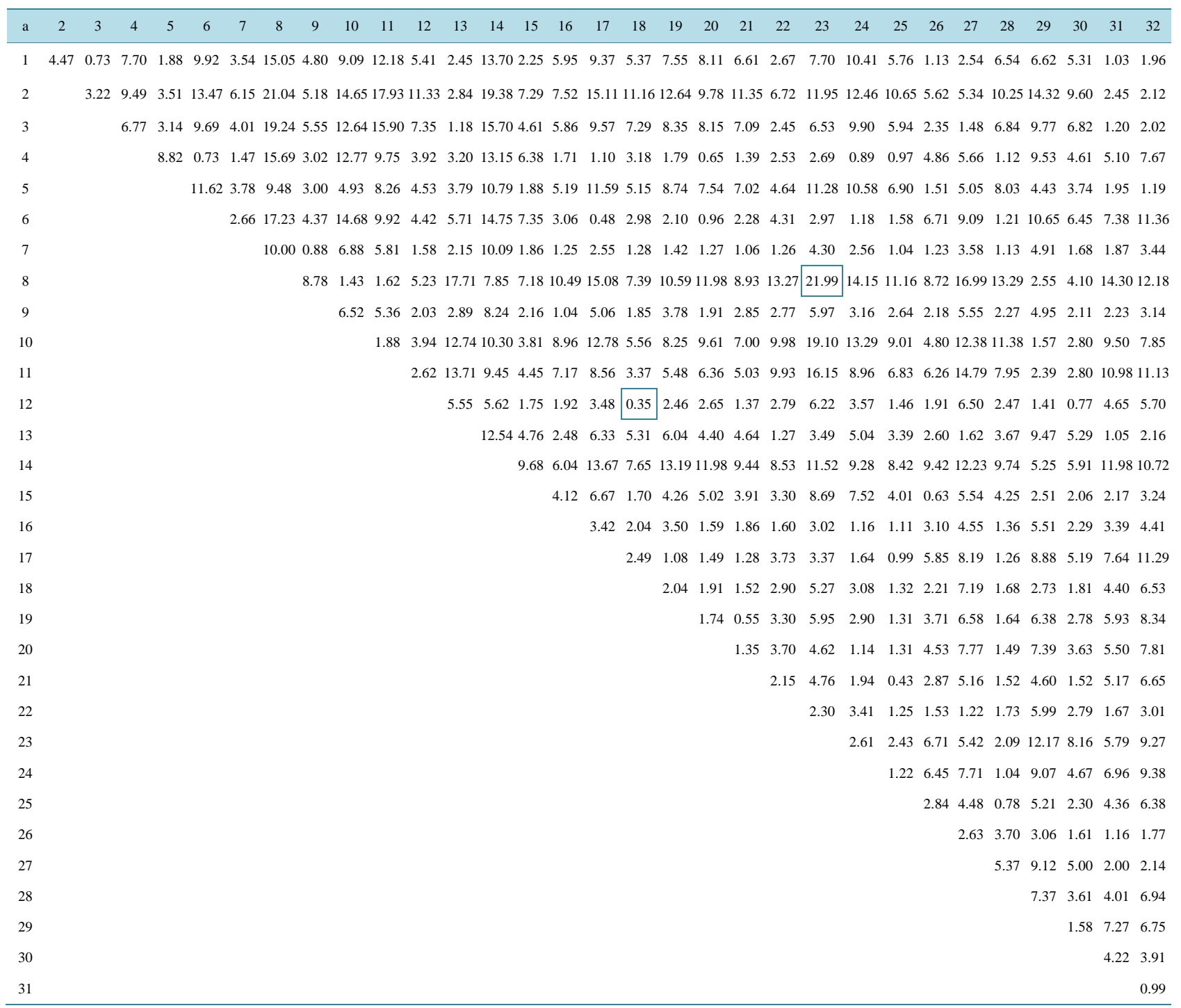

$\mathrm{D}^{2}$ max: 21.99 (Accessions ID 8 (WU $10 \mathrm{~B}$ ) and 23 (IAPAR L 99-98) most dissimilar; $\mathrm{D}^{2}$ min $=0.35$ (Accessions ID 12 (MOGAMI CHIKANARI) and 18 (CO18) most similar). See Table 2 for the names of the accessions 1 - 32.

Only the accessions MTU15 (ID 18) and CO18 (ID 18) have been previously reported to have resistance to Chilo suppressalis and Scirpophaga incertulas in Asia [18]. However, these materials are presented together with the accession IAC 47 used as a control (susceptible to D. saccharalis). The accession from Brazil, BRS PRIMAVERA (ID 29) has been reported to have moderately resistance to D. saccharalis [19] [20]. These accessions were classified in phenotypic Groups I and III by Tocher's grouping method (Table 4) and were separated according to the dispersion of scores based on the CVA clustering method on seven phenotypic characters of rice resistance to $D$. saccharalis (Figure 1).

The classification of IAC 47 as susceptible to D. saccharalis has been reported by other authors [5] [8] [18]. The accession has an internal stem diameter greater than $2.5 \mathrm{~mm}$, a morphological characteristic which is favorable to the growth and development of D. saccharalis. Accessions like SONA, CO18, MTU15, MEARIN, IAPAR L 99-98 occurred in the same group as cultivar IAC 47, according to the multivariate analysis of phenotypic data. 
Table 4. Tocher's grouping method of the 32 accessions of rice based on dissimilarity expressed by Mahalanobis distance estimated from seven characters ${ }^{\mathrm{a}}$.

\begin{tabular}{ccc}
\hline Groups & Number of accessions & Accessions $^{\mathrm{b}}$ \\
\hline I & 21 & $4,6,7,9,12,13,15,16,17,18,19,20,21,22,23,24,25,26,28,30$ and 31 \\
II & 6 & $1,2,3,5,27$ and 32 \\
III & 4 & $8,10,11$ and 29 \\
IV & 1 & 14 \\
\hline
\end{tabular}

${ }^{\mathrm{a} C h a r a c t e r s ~ e v a l u a t e d: ~ n u m b e r ~ o f ~ l i v e ~ l a r v a e ~(N L L) ; ~ i n d i v i d u a l ~ m a s s ~ o f ~ l a r v a e ~ i n ~} \mathrm{~g}$ (IM); external diameter of the stem in mm (ED); internal diameter of the stem in mm (ID); number of total tillers produced after infestation (NTT); number of stems attacked (NSA); number of stems with no larval

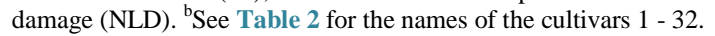

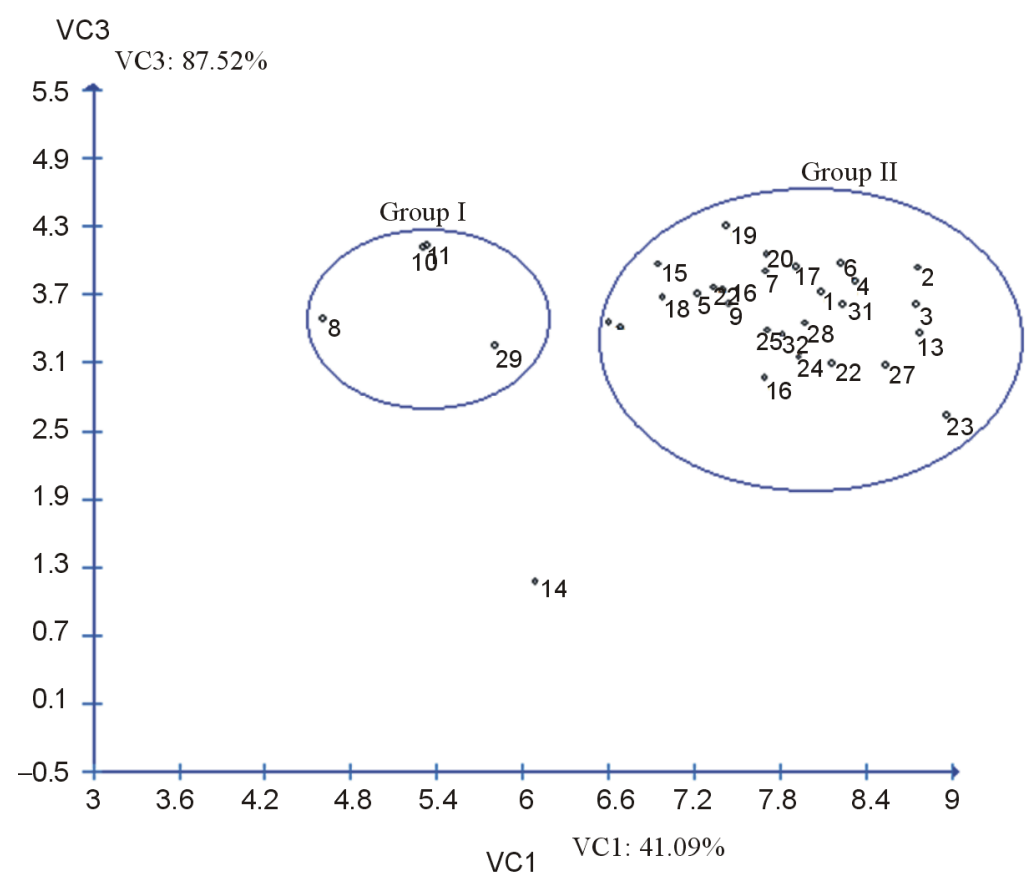

Figure 1. Dispersion of scores of 32 accessions of rice in relation to the three first canonical variables (VC1 and VC3) and cumulative variance (\%) based on seven characters of rice resistance to Diatraea saccharalis. See Table 2 for the names of the cultivars $1-32$.

All of these materials used in this study are representative of the rice mini-core collection of the Embrapa Rice and Beans. Only some of them as IAC 47, BRS PRIMAVERA and "CANELA DE FERRO” were studied for resistance to this borer. This was the first study of the accesses rice. These materials correspond to accessions introduced from different countries and national rice cultivars that have been separated from a core collection. They were selected because due their high genetic variability and its great potential to be used in prebreeding programs. However, more in depth studies are needed to better understand the levels and the mechanisms of resistance involved in these rice accessions to the sugarcane borers.

\section{Conclusions}

According to the morphological traits, different groups of accessions were identified in relation to resistance to D. saccharalis which were useful for diversity analysis. The multivariate analysis was successful in separating accessions into groups in relation to resistance to $D$. saccharalis. The characteristics evaluated should be an important consideration in screening rice accessions for resistance to sugarcane borer.

Other exploratory studies focused on effects of antibiosis and antixenosis could help elucidate the mechanisms of resistance involved for each material. Also, the aid of molecular area can also be a driving tool to identify genes that confer resistance to insect pests. 


\section{Acknowledgements}

The authors thank CAPES (Coordination of Improvement of Higher Education Personnel) for the scholarship conceded the first author. We are grateful to Edmar Cardoso de Moura, Edson D. D. Jacinto and José Francisco A. e Silva for their constant support. This research was financed by Brazilian Agricultural Research Corporantion-Embrapa (Project: 0209030030003).

\section{References}

[1] Wander, A.E. (2006) Cultivation of Upland Rice in the State of Mato Grosso. http://sistemasdeproducao.cnptia.embrapa.br/FontesHTML/Arroz/ArrozTerrasAltasMatoGrosso/

[2] Morais Jr., O.P., Mendes, R.T., Pacheco, L.C.P.S., Pelá, A. and Pelá, G.M. (2013) Influence of Liming and Phosphorus in the Efficiency of Foliar Fertilization with Zinc in Upland Rice. Agrotechnology Journal, 4, 1-16. http://www.prp.ueg.br/revista/index.php/agrotecnologia/article/view/1443

[3] Ferreira, E., Barrigossi, J.A.F., Santos, A.B. and Castro, E.M. (2004) Yield Losses by Stem Borer (Diatraea saccharalis Fab. 1794) (Lepidoptera: Pyralidae) in Upland Rice Gonotypes. Pesquisa Agropecuária Tropical, 34, 99-103. http://www.revistas.ufg.br/index.php/pat/article/view/2332

[4] da Silva Martins, J.F., Barrigossi, J.A.F., de Oliveira, J.V. and da Cunha, U.S. (2009) Status of Integrated Management Pest Insects in Rice in Brazil. http://www.infoteca.cnptia.embrapa.br/handle/doc/875827

[5] da Silva Martins, J.F., Rossetto, C.J. and Roccia, A.O. (1977) Oviposition Preference of Diatraea saccharalis (Fabricius, 1794) in Rice Varieties. Anais da Sociedade Entomológica do Brasil, 6, 64-72.

[6] da Silva Martins, Pinheiro, B.S. and Lowe, J.A. (1978) Nitrogen and Infestation of the Rice Stem Borer, in Flooded Rice. Pesquisa Agropecuária Brasileira, 13, 23-25. http://seer.sct.embrapa.br/index.php/pab/article/view/16794/11114

[7] da Silva Martins, J.F., Tan, N.V. and da Silveira Pinheiro, B. (1981) Resistance of Upland Rice to Stem Borer and Its Association with Plant Morphological Characters. Pesquisa Agropecuária Brasileira, 16, 187-192. https://seer.sct.embrapa.br/index.php/pab/article/view/16775/11099

[8] da Silva Martins, J.F., Parra, J.R.P. and Mihsfeldt, L.H. (1989) Rice Resistance to Stem Borer: I. Evaluation through Larvae Feeding on Stem Pieces. Pesquisa Agropecuária Brasileira, 24, 347-356. https://seer.sct.embrapa.br/index.php/pab/article/view/15094/8854

[9] da Silva Martins, J.F., Parra, J.R.P. and Mihsfeldt, L.H. (1989) Rice Resistance to Stem Borer: II. Evaluation through Larvae Feeding on Artificial Diets Containing Aqueous Extracts of Plants. Pesquisa Agropecuária Brasileira, 24, 357-365.

[10] Sidhu, J.K., Stout, M.J. and Blouin, D.C. (2013) Performance and Preference of Sugarcane Borer, Diatraea saccharalis, on Rice Cultivars. Entomologia Experimentalis et Applicata, 149, 67-76. http://dx.doi.org/10.1111/eea.12111

[11] Afzal, M., Nazir, Z., Bashir, M. and Khan, B. (2009) Analysis of Host Plant Resistance in Some Genotypes of Maize against Chilo partellus (Swinhoe) (Pyralidae: Lepidoptera). Pakistan Journal of Botany, 41,421-428.

[12] Munyiri, S.W., Mugo, S.N., Otim, M., Tefera, T., Beyene, Y., Mwololo, J.K. and Okori, P. (2013) Responses of Tropical Maize Landraces to Damage by Chilo partellus Stem Borer. African Journal of Biotechnology, 12, 1229-1235.

[13] Khush, G.S. (1989) Multiple Disease and Insect Resistance for Increased Yield Stability in Rice. In: IRRI, Ed., Progress in Irrigated Rice Research, Manila, 79-92.

[14] Way, M.O., Reay-Jones, F.P.F. and Reagan, T.E. (2006) Resistance to Stem Borers (Lepidoptera: Crambidae) among Texas Rice Cultivars. Journal of Economic Entomology, 99, 1867-1876. http://dx.doi.org/10.1603/0022-0493-99.5.1867

[15] Hamm, J.C., Sidhu, J.K., Stout, M.J., Hummel, N.A. and Reagan, T.E. (2011) Oviposition Behavior of Diatraea saccharalis (Lepidoptera: Crambidae) on Different Rice Cultivars in Louisiana. Environmental Entomology, 41, 571-577. http://dx.doi.org/10.1603/EN11123

[16] de Oliveira Borba, T.C. (2007) Genetic Diversity and Association Mapping for Yield and Grain Quality of the Improved Access of Core Collection of Rice Embrapa. Ph.D. Dissertation, Federal University of Goiás, Goiânia.

[17] Sousa, D.M.G. and Lobato, E. (2004) Liming and Fertilization for Annual and Perennial Crops. In: Sousa, D.M.G. and Lobato, E., Eds., Cerrado: correção do solo e adubação, Embrapa, 287-289.

[18] Khan, Z.R., Litsinger, J.A., Barrion, A.T., Villa Nueva, F.F.D., Fernandez, N.J. and Taylo, L.D. (1991) World Bibliography of Rice Stem Borers. International Rice Research Institute, Manila.

[19] Lana, A.C., Ferreira, C.M. and Barrigossi, J.A.F. (2003) Environmental and Economic Impact of the Culture of Upland Rice: Case of the BRS Primavera. http://www.infoteca.cnptia.embrapa.br/bitstream/doc/212400/1/comt58.pdf

[20] Ferreira, E., Breseghello, F., da Maia de Castro, E. and Barrigossi, J.A.F. (2000) Upland Rice Resistance to Stem Borer 
(Diatraea saccharalis Fabricius, 1974). http://ainfo.cnptia.embrapa.br/digital/bitstream/item/59056/1/Foco-47.pdf

[21] Vacari, A.M., de Souza Genovez, G., de Laurentis, V.L. and Bortoli, S.A. (2012) Protein Source in Diatraea saccharalis Diet and Its Impact on Production and Quality Control of Cotesia flavipes. Bragantia, 71, 355-361. http://dx.doi.org/10.1590/S0006-87052012005000033

[22] Reis, R. Jr., Lima, E.R., Vilela, E.F. and Barros, R.S. (2000). Method for maintenance of coffee leaves in vitro for mass rearing of Leucoptera coffeellum (Guérin-Méneville) (Lepidoptera: Lyonetiidae). Anais da Sociedade Entomológica do Brasil, 29, 849-854. http://dx.doi.org/10.1590/S0301-80592000000400030

[23] R Development Core Team (2012) R: A Language and Environment for Statistical Computing. R Foundation for Statistical Computing, Vienna. http://www.R-project.org/

[24] Cruz, C.D. and Carneiro, P.C.S. (2006) Biometric Models Applied to the Genetic Breeding. 2nd Edition, Federal Ubiversity of Viçosa, Viçosa.

[25] Cruz, C.D. (2006) Program Genes: A Software in the Area of Genetics and Experimental Statistics. http://www.ufv.br/dbg/genes/Genes_EUA.htm

[26] Suinaga, F.A., Casali, V.W.D., Silva, D.J.H. and Picanço, M.C. (2003) Genetic Dissimilarity among Sources of Resistance of Lycopersicon spp. to Tuta absoluta (Meyrick, 1917) (Lepidoptera: Gelechidae). Revista Brasileira de Agrociência, 9, 371-376. http://periodicos.ufpel.edu.br/ojs2/index.php/CAST/article/view/644/645

[27] Moreira, G.R., Silva, D.J.H., Picanço, M.C., Peternelli, L.A. and Caliman, F.R.B. (2005) Genetic Diversity among Tomato Accessions Infested by Different Tomato Leaf Miner Populations. Horticultura Brasileira, 23, 893-898. http://dx.doi.org/10.1590/S0102-05362005000400006

[28] Hosseini, S.Z., Babaeian-Jelodar, N. and Bagher, N. (2010) Evaluation of Resistance to Striped Stem Borer in Rice. Biharean Biologist, 4, 67-71.

[29] Sarwar, M. (2012) Study on the Non Aromatic Rice (Oryza sativa L.) Varietals Resistance to Rice Stem Borers (Lepidoptera: Pyralidae) and Yield Factors. International Journal of Agronomy and Plant Production, 3, 159-163. 
Scientific Research Publishing (SCIRP) is one of the largest Open Access journal publishers. It is currently publishing more than 200 open access, online, peer-reviewed journals covering a wide range of academic disciplines. SCIRP serves the worldwide academic communities and contributes to the progress and application of science with its publication.

Other selected journals from SCIRP are listed as below. Submit your manuscript to us via either submit@scirp.org or Online Submission Portal.
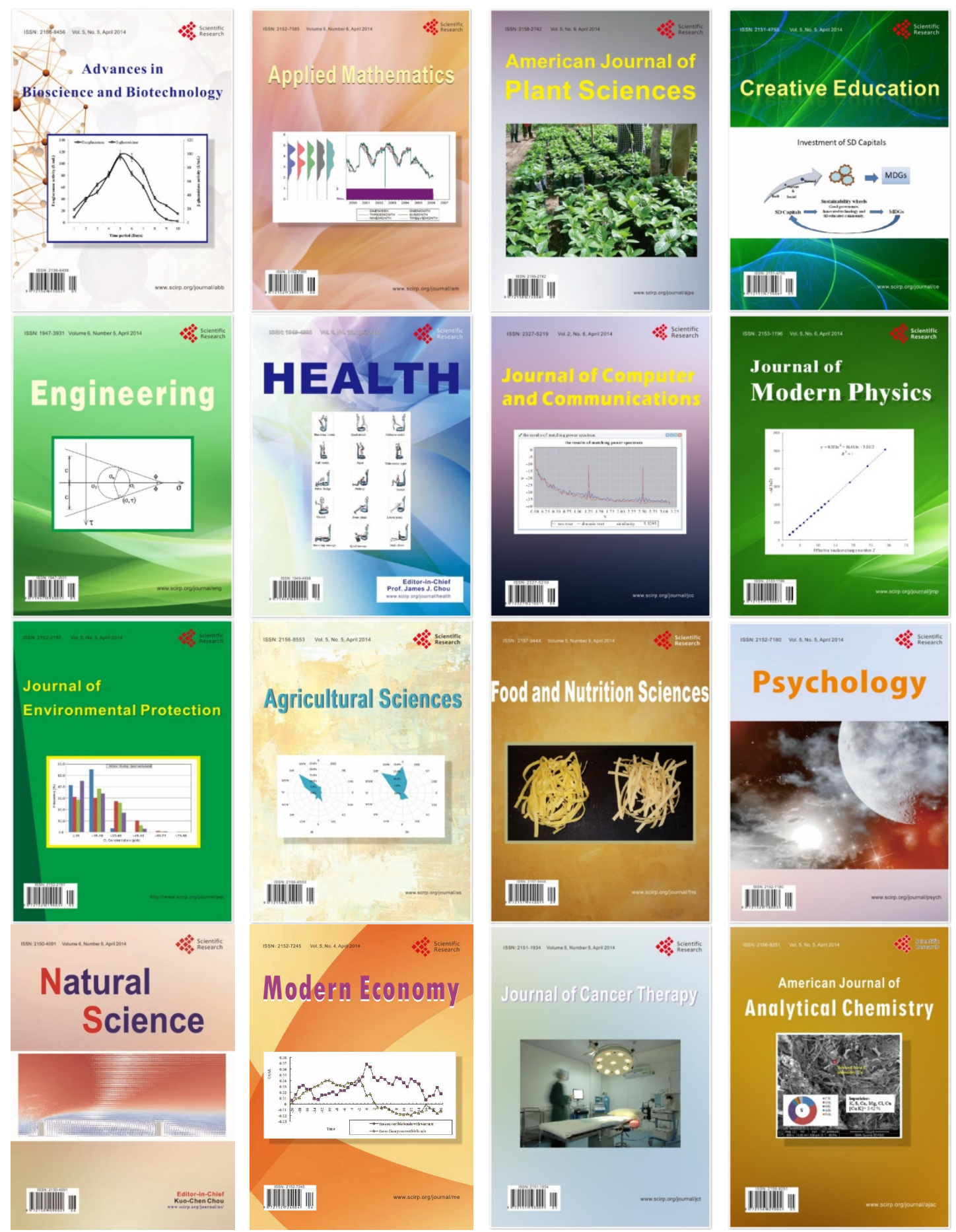